\title{
The biopharmaceutical anomaly
}

\author{
Investment and funding has continued to flow into biotech, unlike most business sectors. But with healthcare \\ and hospital budgets increasingly under pressure, do belt-tightening and consolidation lie ahead? Melanie Senior \\ investigates, with additional reporting by Riku Lähteenmäki.
}

T he biopharmaceutical industry largely has been spared from the public market rout that has gutted most economic sectors since COVID-19 hit. After an initial, indiscriminate shock to stock prices in March 2020, investment in biotech companies listed on the stock exchanges has actually increased. The Nasdaq Biotechnology Index emerged from the slump to reach a five-year high - up 11\% since the start of the year, following a $20 \%$ rise in 2019. Biotech initial public offering (IPOs) have also picked up; in June, the over two dozen 2020 listings had together raised nearly $\$ 8$ billion - more than over the same period in 2019. In early June, CAR-T cell therapy maker Legend Biotech raised \$424 million in the largest ever Nasdaq listing by a Chinese biotech.

"The capital markets remain open and active," to the surprise of many, says Geoffrey Porges, senior biopharmaceuticals analyst at SVB Leerink. The non-

discretionary nature of healthcare - and the sector's key role in finding solutions to the pandemic - have also attracted a flood of generalist and retail investors as they flee struggling sectors like retail, restaurants and airlines. Private biotech financing also had a record first quarter. The pandemic, which has been poison to most sectors of industry, has brought funds to biopharmaceutical enterprises from an even wider spread of investors than normal.

\section{Crisis? What crisis?}

For some biotech companies, listing now - in the midst of what economists call the worst recession in living memory - is easier than in late 2019, when the ChinaUS trade war caused market jitters. ADC Therapeutics, for instance, pulled an IPO in October 2019 and raised an oversubscribed \$235 million in early May 2020 (Table 1). Others are seizing the advantage to raise money, even if they don't really need to: gene therapy venture Generation Bio raised \$230 million in a June IPO, after raising $\$ 110$ million in private money just four months earlier. Its assets are still preclinical. So are those of Boston-based gene therapy group Akouos, which recently filed for a \$100-million IPO, having raised $\$ 105$ million in a series B in March.

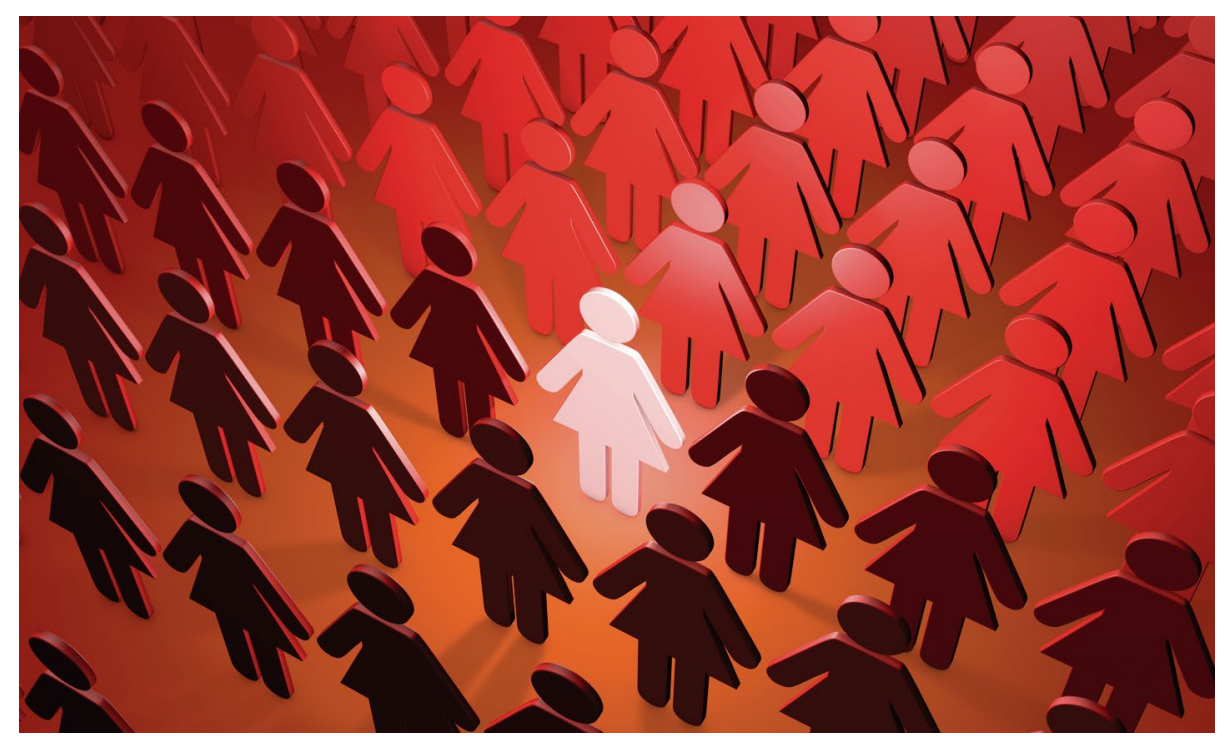

Ruslan Grechka / Alamy Stock Photo.

Follow-on public financing has also been healthy, topping $\$ 19$ billion so far this year, including almost $\$ 2$ billion raised by RNA-focused Moderna in two separate share offerings in February and May 2020 the earlier one at $\$ 19$ per share, the later at four times that. Moderna is the breakout 'COVID-19 performer' so far: its shares have trebled since the end of 2019 on the back of heated excitement around its RNA-based vaccine candidate against the novel coronavirus (SARS-CoV-2), slated to start phase 3 trials in July. (Press-released interim data on eight patients from a small study led by the US National Institute of Allergy and Infectious Diseases claimed that the candidate, mRNA-1273, generated an antibody response similar to that seen in convalescing patients.)

Valued at over $\$ 23$ billion, loss-making Moderna is just one of a growing list of biotechs who have mobilized resources to find a vaccine or therapeutic for COVID-19and seen their shares rise as a result. Also riding the COVID-19 wave: Gilead Sciences, whose failed hepatitis $\mathrm{C}$ virus (HCV) small-molecule candidate remdesivir, an injectable nucleoside analog that inhibits viral RNA-dependent RNA polymerase, was the first COVID-19 therapy to receive US Food and Drug Administration (FDA) Emergency Use Authorization. Regeneron's $60 \%$ share-price gain since the start of the year comes thanks to a monoclonal antibody $(\mathrm{mAb})$ duo due to enter the clinic in June and rheumatoid arthritis drug Kevzara (sarilumab), a human IgG1 mAb targeting the interleukin- 6 receptor, being investigated as a therapy for patients with severe COVID-19 disease. Infectious-disease- and immunology-focused Vir Biotechnology has also nearly trebled in value since January, to $\$ 4$ billion, after announcing COVID-19-related collaborations on antibody therapies with GlaxoSmithKline and Alnylam Pharmaceuticals, itself up 20\% since the start of the year.

By mid-May 2020, there were over a hundred treatments and more than a dozen vaccine candidates in human testing across the wider biopharmaceuticals industry, academic institutions and non-profits. This extraordinary effort is in part enabled by the healthy financing environment for biotech during 2019 (and much of the previous decade). Last year saw large boosts to industry revenue, even higher rises in $\mathrm{R} \& \mathrm{D}$ spending, and chart-topping up-front partnership financing. 
Table 1 | Top ten IPOs of 2019

\begin{tabular}{|c|c|c|c|c|}
\hline Company (lead underwriters) & $\begin{array}{l}\text { Amount raised } \\
\text { ( } \$ \text { millions) }\end{array}$ & $\begin{array}{l}\text { Date } \\
\text { completed }\end{array}$ & $\begin{array}{l}\text { Listing } \\
\text { location }\end{array}$ & $\begin{array}{l}\text { Phase of } \\
\text { development }\end{array}$ \\
\hline Genmab (BofA Merrill Lynch, Morgan Stanley) & 582 & 17 July & $\mathrm{NASDAQ}^{\mathrm{a}}$ & Market \\
\hline 10X Genomics (J.P. Morgan, Goldman Sachs, BofA Merrill Lynch, Cowen) & 449 & 12 September & NASDAQ & Market \\
\hline $\begin{array}{l}\text { BridgeBio Pharma (J.P. Morgan, Goldman Sachs, Jefferies, SVB Leerink, Piper Jaffray, } \\
\text { BMO Capital Markets, Raymond James) }\end{array}$ & 401 & 26 June & NASDAQ & Phase 3 \\
\hline $\begin{array}{l}\text { Adaptive Biotechnologies (Goldman Sachs, J.P. Morgan, BofA Merrill Lynch, Cowen, } \\
\text { Guggenheim Securities, William Blair, BTIG }\end{array}$ & 345 & 26 June & NASDAQ & Market \\
\hline $\begin{array}{l}\text { CStone Pharmaceuticals (Goldman Sachs, Morgan Stanley, UBS, China Merchants } \\
\text { Securities }\end{array}$ & 328 & 25 February & HKEX & Phase 3 \\
\hline Gossamer Bio (BofA Merrill Lynch, SVB Leerink) & 317 & 7 February & NASDAQ & Phase 2 \\
\hline Cellid (Morgan Stanley, Citic CLSA) & 277 & 20 February & KOSDAQ & Phase $1 / 2$ \\
\hline Alphamab Oncology (Morgan Stanley, Citic CLSA) & 234 & 12 December & HKEX & Phase 3 \\
\hline IGM Biosciences (Piper Jaffray) & 201 & 12 December & & Preclinical \\
\hline $\begin{array}{l}\text { Turning Point Therapeutics (Goldman Sachs, SVB Leerink, Wells Fargo, Canaccord } \\
\text { Genuity) }\end{array}$ & 191 & 18 April & NASDAQ & Phase $1 / 2$ \\
\hline
\end{tabular}

${ }^{\mathrm{G}}$ GenMab listed in 2000 on the Danish exchange. HKEX, Hong Kong Exchanges; KOSDAQ, Korea Exchange. Source: BCIQ BioCentury Online Intelligence

The COVID-19 effort has generated its own flurry of deals - including, most recently, Merck's May 2020 acquisition of private Austrian biotech Themis, with its measles virus vector-based vaccine technology. The pandemic has not curbed big biotech or big pharma's broader pipeline hunger, either. Non-COVID-19-related deal-making has slowed, but not stopped. It is mostly restricted to partners with an existing relationship. (Carrying out first-time meetings and due diligence over video conferencing is tricky.) Prices are holding up, at least for popular assets. In late May, Gilead bought a \$200-million equity stake in Hayward, California-based Arcus Biosciences, at a price nearly triple the company's valuation during most of 2019. The deal mirrored Gilead's noteworthy 2019 collaboration with Galapagos of Mechelen, Belgium - in structure, if not size. A further $\$ 175$ million up front sealed Gilead's access to a palette of cancer drug candidates, led by a humanized IgG1 mAb targeting TIGIT (T-cell immunoreceptor with immunoglobulin and ITIM [immunoreceptor tyrosine-based inhibitory motif] domains) in phase 2 trials for non-small-cell lung cancer, in various combinations with the anti-PD1 (programmed cell death receptor 1) fully human IgG4 mAb zimberelimab and AB928, a small-molecule adenosine A2a/A2b receptor antagonist. (On March 2, before the pandemic roiled markets, Gilead forked out $\$ 4.9$ billion, also at a healthy premium, for five-year-old immune-oncology firm Forty Seven and its humanized IgG4 4 anti-CD47 $\mathrm{mAb}$ antibody magrolimab, in phase 2 trials

\section{Box 1 | The numbers}

Nature Biotechnology has published a report on public biotech companies using a similar methodology since 1996. Our definition of what constitutes a biotech company has changed with the industry, as have our methods for gathering the information that powers this article. We generally include R\&D-driven companies built on applications of biological organisms, systems or processes, or the provision of specialist services that facilitate biological understanding. We exclude pharmaceutical companies, medical device firms and contract research organizations to better focus on the unique attributes and situations that make up the research-driven biotech sector.

The data were provided by consultants Ernst \& Young. The top-ten lists and other aggregate lists are sourced appropriately, although mostly they are generated by an analysis of data supplied by BioCentury. In this regard, because investors do not stratify the biotech sector as stringently as Nature Biotechnology, we used money figures from across the biotech and biopharmaceutical arena to best highlight trends. Companies delisted in 2019 from major exchanges were excluded.

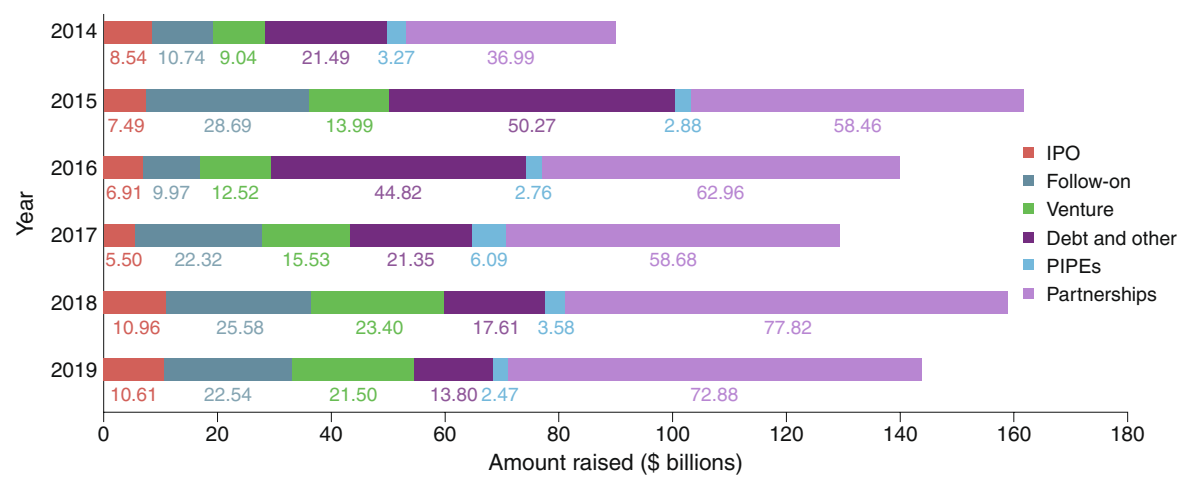

Fig. 1 | Global biotech financing. Financing over the past six years. Source: BCIQ BioCentury Online Intelligence. 
for myelodysplastic syndrome and acute myelogenous leukemia.)

The sector's public prominence amid the pandemic may also have reduced the threat of immediate curbs on US drug pricing, according to many analysts - a threat that cast a shadow over the industry during 2018 and 2019. President Trump is looking to the sector to help him navigate out of the lockdown, restart the economy and win another election: hardly the time to clobber it with unfriendly new rules, such as an international reference price index.

\section{Clouds may be looming}

It's unclear whether the good times will last. "It's quite understandable that companies are raising capital now, while markets remain strong," says Joshua Schimmer, senior managing director of biotech at Evercore. "We may still see a lot of volatility," he says though acknowledging that, if the sector continues to weather the crisis as well as it has been, "it's hard to imagine what else could derail it."

Until now, trillions of dollars of government support have cushioned the full impact of lockdown on employment and household budgets (including, in the United States, the affordability of health insurance) and created a sharp disconnect between stock markets and the underlying economy. If and when that support dries up and markets collapse, all but the best-capitalized companies could suffer. Negative news from the COVID-19 pipeline will also take the heat off healthcare stocks and some firms' ability to raise capital. A second lockdown before a drug or vaccine is found will mean further trial delays across non-COVID-19 R\&D, stretching the resilience of biotech companies and their investors even more.

Slowing markets will disproportionately affect smaller and pre-revenue companies, including those whose clinical trials have ground to a halt during the pandemic lockdown. The biotech industry has raised over $\$ 140$ billion in debt over the last five years - including a further $\$ 10.9$ billion so far in 2020. Some of this debt is plain vanilla loans to large, cash-generative biotechs like Amgen. But 'convertible' loans - which can be converted into equity at a later date, such as at a subsequent financing round - have also become more popular over the past several years among smaller, pre-revenue companies, in part because they delay the tricky business of valuing such groups. In early March 2020, BridgeBio Pharma raised a higher-than-anticipated $\$ 475$ million in convertible notes; Gossamer Bio raised \$200 million's worth in May, alongside a smaller equity offering.

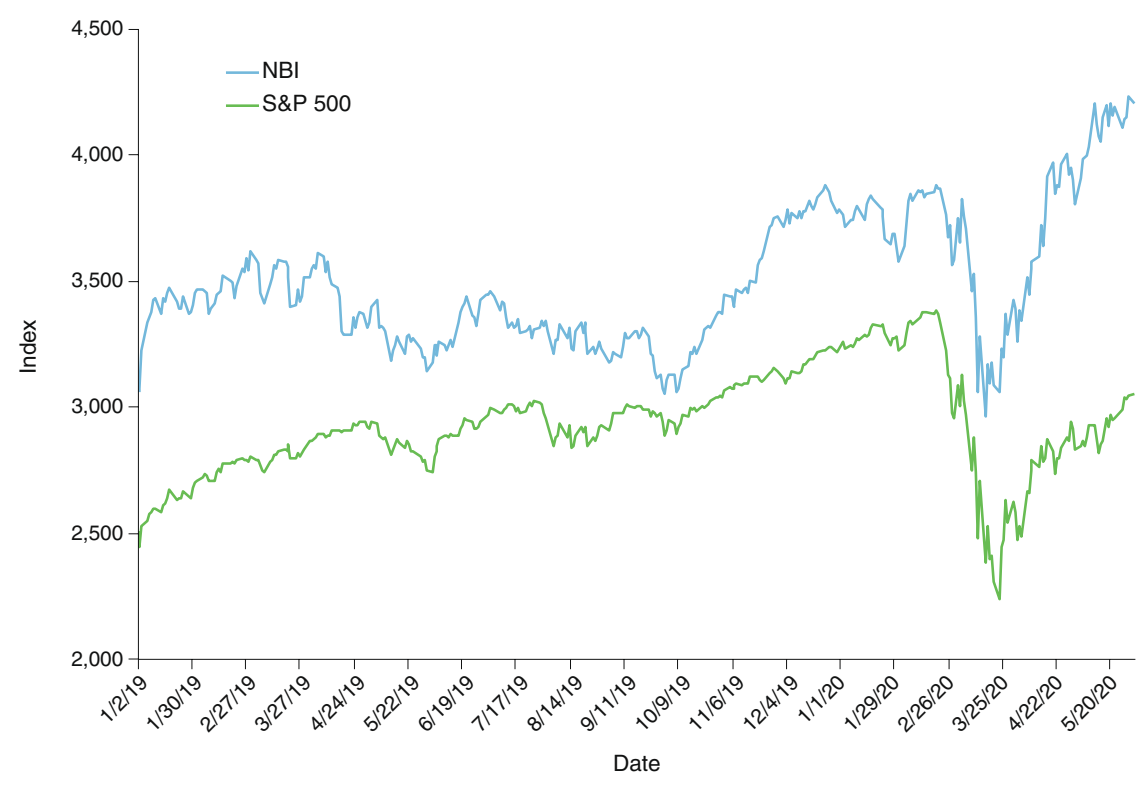

Fig. 2 | Nasdaq Biotechnology Index over time. As of 6/1/2020. NBI, Nasdaq Biotechnology Index; S\&P, Standard \& Poor's 500 Index.

\section{Box 2 | Heady IPOs in 2019}

Danish antibody company Genmab's second coming (it listed in 2000 on the Danish stock exchange) topped the overall IPO ranks. It raised $\$ 582$ million in July, boosted by a mature portfolio including three approved (partnered) drugs and 20 clinical development programs (Table 1). The year marked Nasdaq's emergence as the definitive market of choice for European biotechs, offering access to more capital, more specialist investors and greater liquidity than local European exchanges. All but one of the top eight European-company IPOs were in the United States. German cancer immunotherapy and vaccine company BioNtech raised \$148 million in October; its upward share trajectory received a COVID-19 boost in 2020 as the company advanced a handful of RNA-based COVID-19 vaccine candidates into trials. BridgeBio Pharma raked in over \$400 million in 2019's third-largest Nasdaq IPO, with its enticing suite of clinical-stage precision medicines tackling rare genetic diseases and genetically defined cancers.

Three of 2019's top ten IPOs were in Asia. This marks the continuing rise

In good times, borrowing is easy, and it allows companies to avoid diluting the value of their shares (which is what happens in an of the region's home-grown innovative biotech sector, spurred on by the Hong Kong stock exchange's recent acceptance of pre-revenue companies and the ongoing US-China trade war, which has driven Chinese money back home. The Hong Kong IPO scene was bookended by two cancer-focused biotechs: CStone Pharmaceuticals, which raised $\$ 328$ million in February, and Alphamab Oncology, which drew in \$234 million in December.

2019's top ten IPO cohort was a relatively young one: six were founded within the last decade; three (BridgeBio, Gossamer Bio and CStone Pharmaceuticals) were just four years old. The year's mostly buoyant IPO market also continued to draw in non-traditional funders, including crossover investors (which can invest in both private and public companies), private equity investors (normally focused on revenue-generating firms) and sovereign wealth funds. Deep-pocketed firms like Blackstone, KKR, RA Capital and Bain Capital put money behind pre-IPO candidates, helping bounce them onto public markets and draw in more public funds.

equity offering). But in tougher times, some companies may be unable to service or repay their debt, leading to bankruptcy — or a fire 
sale. Convertible loans, whose terms may vary from months to several years, may also need to be repaid in full if a company fails to meet fundraising targets; lenders get priority over shareholders in the case of insolvency.

There are already signs of trouble. Companies relying on revenues from a narrow portfolio of hospital drugs have had to cut costs or sell out at bargain prices. In May 2020, Portola Pharmaceuticals, which sells Andexxa (recombinant human coagulation factor Xa inactivated-zhzo) for excessive bleeding, was picked up by Alexion Pharmaceuticals for $\$ 1.4$ billion, or \$18 per share - well below Portola's pre-COVID-19 share price of close to $\$ 30$. Sage Therapeutics - whose \$575-million follow-on financings topped the league in 2018 and 2019 - in early April announced cuts to head count and costs, facing dwindling sales of its hospital-administered postpartum depression medicine Zulresso (brexanolone) and an idle sales force.

On the IPO markets, Pitchbook reports a flurry of listings by 'shell' companies (also known as special-purpose acquisition companies), set up to buy promising yet cash-hungry targets. Tübingen, Germany-based T-cell cancer immunotherapy-focused Immatics Biotechnologies in March 2020 reverse-merged into Nasdaq-listed Arya Sciences Acquisition, raising $\$ 252$ million.

COVID-19's full impact on the sector has yet to play out. A funding squeeze may lead to better capital efficiency - a skill some companies lost amid the funding bonanza of the last few years. Industry's rapid, collaborative response to the virus outbreak, along with some promises, such as from AstraZeneca, to provide any eventual vaccine at cost, may help restore the reputation of a sector criticized for price-gouging, hiding bad data and neglecting diseases of the developing world.

Yet the drug pricing debate, if pushed down the road, hasn't gone away. The sector's value to society has never been clearer, but what society can afford to pay for that value is far less so, particularly as economies reopen amid mass unemployment and heavily indebted governments. "It's a delicate time for the industry," says one analyst.

Longer term, this pandemic should mean more public funding for the life sciences, driving emboldened private investors to follow. "Investment into pharma and healthcare will continue to increase," predicts one UK-based fund manager.

The focus of this investment may change, though. Governments are now much more likely to prioritize vaccines, anti-infectives and preventative care. High-priced gene

Table 2 | Top ten follow-on financings of 2019

\begin{tabular}{lll} 
Company & Amount raised (\$ millions & Date \\
\hline Sage Therapeutics & 575 & $02 / 27 / 2019$ \\
Ascendis Pharma & 575 & $03 / 05 / 2019$ \\
Seattle Genetics & 575 & $07 / 23 / 2019$ \\
Reata Pharmaceuticals & 505 & $11 / 13 / 2019$ \\
\hline Amarin & 460 & $07 / 18 / 2019$ \\
Deciphera Pharmaceuticals & 460 & $08 / 14 / 2019$ \\
Alnylam Pharmaceuticals & 388 & $01 / 14 / 2019$ \\
Sarepta Therapeutics & 375 & $03 / 05 / 2019$ \\
Blueprint Medicines & 345 & $03 / 28 / 2019$ \\
Ultragenyx Pharmaceutical & 340 & $02 / 26 / 2019$ \\
\hline
\end{tabular}

Source: BCIQ BioCentury Online Intelligence

Table 3 | Top ten revenue-producing biotechs of 2019

\begin{tabular}{lll} 
Company & $\mathbf{2 0 1 9}$ revenue (\$ millions) & \% change from 2018 \\
\hline Amgen & 23,362 & $-2 \%$ \\
Gilead Sciences & 22,449 & $1 \%$ \\
Biogen & 14,378 & $7 \%$ \\
Regeneron Pharmaceuticals & 7,863 & $17 \%$ \\
Alexion Pharmaceuticals & 4,991 & $21 \%$ \\
Vertex Pharmaceuticals & 4,163 & $37 \%$ \\
Illumina & 3,543 & $6 \%$ \\
bioMérieux & 3,002 & $8 \%$ \\
Incyte & 2,159 & $15 \%$ \\
Novozymes & 2,159 & $-2 \%$ \\
\hline
\end{tabular}

Source: Ernst and Young

and cell-based therapies and drugs for rare diseases - hot spots in the years up to and including 2019 - may rapidly be viewed as less affordable as population health measures are prioritized, and if economists' predictions of a deep, dark recession bear out. "I worry that much of the money flowing into the sector today isn't going into the right places," says the fund manager.

\section{A look back at 2019}

2019 can seem either a long time ago or just yesterday, thanks to the distorting effect of a global pandemic. Yet public biotech companies' resilience so far is due, in part, to 2019's healthy financials, increased revenues and robust investment in research and development (Box 1 and Supplementary Table 1).

Capital continued to flow strongly into the biotech sector in 2019, even if the figures didn't quite reach the heady heights achieved in 2018. Total public biopharma fundraising was over $\$ 122$ billion, with IPO and follow-on offerings bringing in about $\$ 33$ billion of that (Fig. 1). Up-front (committed) partnership monies topped $\$ 14$ billion, beating 2018, largely thanks to Gilead's \$3.95-billion payment to partner Galapagos. The Nasdaq Biotechnology Index also performed a lot better than in 2018. Much of the $20 \%$ overall rise came in the last quarter of 2019, more than making up for 2018's $9 \%$ decline (Fig. 2).

The \$10.6-billion total IPO haul - only a fraction below the previous year's - was dominated, as usual, by listings in the United States. But Asia’s share of IPO money increased from $32 \%$ to $42 \%$, filling the hole left by a dwindling number of European listings. Targeted cancer immunotherapy and rare genetic diseases remained white-hot (Table 1 and Box 2).

Follow-on financing in 2019 totaled $\$ 22.5$ billion - a slight fall from 2018, but still including four late-stage companies that each raised over half a billion (Table 2). Two of those, cancer-focused antibody-drug conjugate (ADC) company Seattle Genetics and depression-focused Sage Therapeutics, were also in 2018's top ten. Three dozen 


\section{Box 3 | Vertex wins chase for revenues}

Amgen clung onto number one in the revenue league, cashing in over $\$ 23$ billion $1 \%$ below its 2018 haul (Table 3 ).

A legal victory against Sandoz in August 2019 pushed biosimilar competition to number-one earner Enbrel (etanercept) years down the road; Enbrel price increases and volume growth across other products enabled the biotech to neutralize the impact of price erosion and competition elsewhere across its aging portfolio, including to Neulasta (pegfilgrastim; recombinant methionyl human G-CSF (filgrastim) conjugated to monomethoxypolyethylene glycol). Management declared the start of a new era of product-driven growth; fittingly, $\mathrm{R} \& \mathrm{D}$ spending grew $10 \%$. The company also expanded its geographic reach, paying $\$ 2.7$ billion for a minority stake in China's BeiGene, which will commercialize Amgen's existing cancer drugs in China and co-develop new ones.

Gilead's \$22.4 billion in 2019 revenues were almost unchanged, signaling a recovery from 2018's declines. A growing HIV portfolio, driven by Biktarvy triple therapy - a combination of small molecules bictegravir (HIV integrase inhibitor), emtricitabine (nucleoside analog inhibitor of HIV reverse transcriptase) and tenofovir alafenamide (nucleotide analog inhibitor of HIV reverse transcriptase) plus near doubling of sales of its CAR-T cell therapy Yescarta (albeit from a low base) allowed the big biotech to blunt the impact of competition to its HCV franchise. That HCV expertise keeps on giving, though: Gilead's value has risen by $>12 \%$ since the end of 2019, to $\$ 92$ billion, thanks to its failed HCV drug candidate remdesivir. On May 1, the adenosine analog became the first COVID-19 therapy to receive FDA Emergency Use Authorization.

Vertex's 33\% value uptick over 2019 worth $\$ 14$ billion in market capitalization tracked a similarly sized revenue increase. Both were driven by uptake of its most recent cystic fibrosis medicine combination Symdeko (also called Symkevi; small molecules tezacaftor/ivacaftor and ivacaftor) and early US approval and launch of Trikafta (elexacaftor/tezacaftor/ ivacaftor and ivacaftor), targeted at patients with at least one F508del mutation in the cystic fibrosis transmembrane conductance regulator (CFTR) gene. Vertex bumped up its R\&D spending by $24 \%$.

Biogen's 10\% drop in market capitalization over the year hid a very bumpy ride. High-profile Alzheimer's disease candidate aducanumab, a fully human anti-amyloid- $\beta$ IgG1 mAb, failed futility analyses in two phase 3 trials in March, wiping a quarter off Biogen's value. But October brought a surprise resurrection attempt, when Biogen announced it would submit the drug to FDA after all, based on a new analysis of the data that included longer-term data from some patients. Submission has since been delayed, but this ray of hope, plus ex-US growth for spinal muscular atrophy drug Spinraza (nusinersen), helped nudge Biogen revenues to $\$ 14.3$ billion, slightly higher than the previous year. R\&D spending fell $13 \%$.

Biogen generates three times Vertex's revenue, but Vertex is valued more highly, given its growth prospects. COVID-19 has widened that gap: Vertex's market capitalization has since soared beyond $\$ 73$ billion, while Biogen's has fallen.

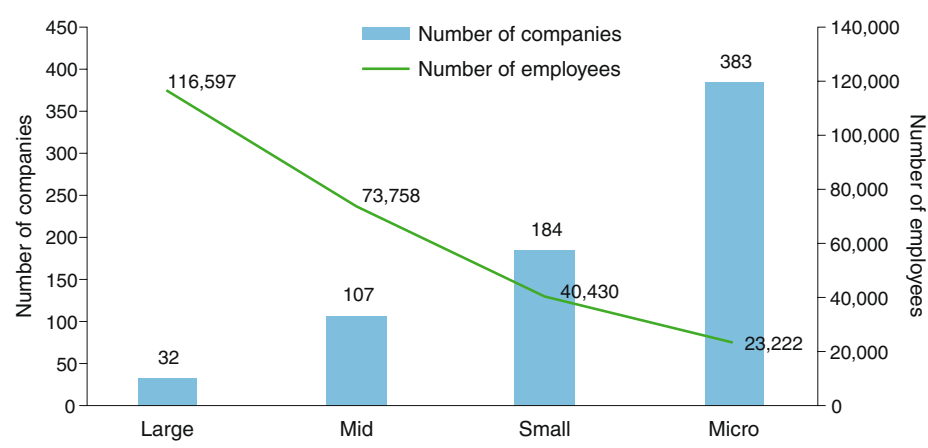

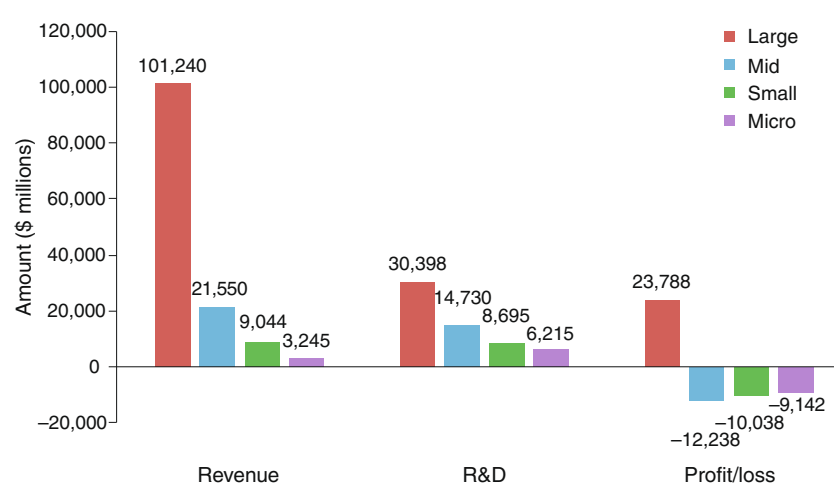

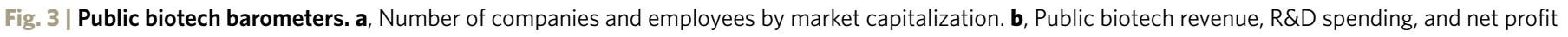
and loss. Large cap, $\geq \$ 5$ billion; mid-cap, $\$ 1$ billion to $<\$ 5$ billion; small cap, $\$ 250$ million to $<\$ 1$ billion; micro-cap, $<\$ 250$ million.

others banked over $\$ 200$ million each to fuel their pipelines; gene-therapy venture Sarepta Therapeutics and Agios Pharmaceuticals, focused on cancer and rare genetic diseases, featured in that category both years.

\section{Higher revenues spawn R\&D splurge}

For many of the sector's large- and mid-cap companies, 2019 was a good year. Large-caps recovered from a miserable twelve months during which generics, biosimilars and actual and threatened pricing curbs caused investor caution. A new cohort of unicorns benefited from profligate private investment and average IPO sizes above $\$ 100$ million. Total industry revenues were up $11 \%$ to $\$ 135$ billion, with Amgen, Gilead and Biogen accounting for $44 \%$ of that (Table 3, Box 3 and Supplementary Table 1). But the biggest revenue rises were among mid- and small-cap companies, whose aggregate revenues were up $19 \%$ and $21 \%$, respectively, thanks to rapidly progressing pipelines and portfolios, including across cancer and rare diseases. The top ten revenue-generating companies (including both product and partnership revenue) accounted for almost two-thirds of the total.

The increase in revenues coincided with increased industry R\&D spending - an increase even more substantial than that over the previous year. A total of $\$ 60.1$ billion in R\&D spending represented an increase of $27 \%$ and a healthy $44.5 \%$ share of these larger revenues (Fig. 3). In 2018, just $39 \%$ was reinvested into R\&D. Seven companies spent more than a billion dollars on R\&D, including Gilead, which doubled its $\mathrm{R} \& \mathrm{D}$ spending to over $\$ 8$ billion as it 


\section{Box 4 | Rising R\&D spending targets rare diseases}

Sixty-six biotechs doubled or more than doubled their R\&D bills in 2019. Sixteen of those spent more than $\$ 100$ million on $\mathrm{R} \& \mathrm{D}$. Over half of those 16 are working on drugs for rare diseases, including Akcea (whose spend rose to almost $\$ 300$ million, up 125\%), newly listed immunology player Gossamer Bio, autoimmune- and inflammatory-diseases focused Viela Bio (which in May 2020 raised another \$169 million via a follow-on stock offering) and Netherlands-based Argenx, which spent
\$222 million in 2019, up 132\%. Biotechs working on cellular therapies (Autolus Therapeutics and Rubius Therapeutics) and RNA-based medicines (Dicerna) were also on the list.

Investors are excited by the potential of RNA- and cell-based technologies to generate a range of new medicines. Rare disease therapies continue to be attractive thanks to unmet need, low competition and relatively high prices - though these dynamics may soon start to shift.
United Therapeutics' chart-topping $228 \%$ increase in R\&D spend was due to an \$800-million up-front payment to Arena Pharmaceuticals for a global license to phase 3 pulmonary arterial hypertension drug ralinepag, a prostacyclin receptor agonist. Enrollment into those late-stage trials is on pause. (Arena's R\&D spend also doubled in 2019; on June 1, the company took advantage of frothy public markets to raise $\$ 316$ million in a follow-on share offering.)

Table 4 | Top ten R\&D spenders of 2019

\begin{tabular}{lll} 
Company & R\&D spending 2019 (\$ millions) & \% change from $\mathbf{2 0 1 8}$ \\
\hline Gilead Sciences & 8,306 & $98 \%$ \\
\hline Amgen & 4,116 & $10 \%$ \\
\hline Regeneron Pharmaceuticals & 3,037 & $39 \%$ \\
\hline Biogen & 2,265 & $-13 \%$ \\
\hline Vertex Pharmaceuticals & 1,755 & $24 \%$ \\
\hline United Therapeutics & 1,174 & $228 \%$ \\
\hline Incyte & 1,154 & $-4 \%$ \\
\hline BeiGene & 927 & $37 \%$ \\
Alexion Pharmaceuticals & 886 & $21 \%$ \\
\hline Sarepta Therapeutics & 734 & $83 \%$ \\
\hline
\end{tabular}

Source: Ernst and Young

seeks to fill the hole left by its declining HCV franchise. Regeneron's \$3 billion R\&D investment in 2019 was up almost $40 \%$ on the previous year, leading to lower net income, despite revenue growth of
$17 \%$ driven by wet age-related macular degeneration treatment Eylea (aflibercept; a recombinant fusion of portions of the extracellular domains of human vascular endothelial growth factor (VEGF) receptors 1 and 2 to the Fc portion of a human IgG1) and a higher profit-contribution from partner Sanofi's sales of atopic dermatitis drug Dupixent (dupilumab; a human IgG4 mAb targeting the interleukin- $4 \mathrm{R} \alpha$ subunit) (Table 4 and Box 4).

Beijing-based BeiGene, working on targeted immuno-oncology drugs; rare-disease companies Alexion and BioMarin Pharmaceuticals; gene-therapy player Sarepta; and RNA interference (RNAi)-focused Alnylam Pharmaceuticals all spent more than half a billion dollars each on R\&D.

\section{New approvals, modalities - and sources of capital}

Cancer and rare diseases, plus RNA-based technologies, antibodies, ADCs and gene- and cell therapies enjoyed continued popularity in 2019, as reflected in the list of highest R\&D spenders, as well as those with the biggest increases in R\&D. These new modalities were boosted by regulatory

\section{Box 5 | Approvals keep investors interested}

Alnylam's growing product franchise its second drug, Givlaari (givosiran), a synthetic siRNA molecule against 5-aminolevulinic acid synthase, was approved for acute hepatic porphyria caught the attention in early 2020 of private equity group Blackstone Life Sciences, which agreed to provide $\$ 2$ billion to bridge the group across to financial self-sustainability. Alongside a \$750-million loan, Blackstone bought half the royalties owed to Alnylam by Novartis for cholesterol medicine inclisiran, as well as taking an equity stake.

Seattle Genetics' second drug, Padcev (enfortumab vedotin-ejfv; an ADC comprising a fully human anti-nectin-4
IgG1 $\kappa \mathrm{mAb}$ conjugated to four molecules of the small-molecule microtubule-disrupting agent monomethyl auristatin E (MMAE) via a protease-cleavable maleimidocaproyl valine-citrulline linker) for metastatic urothelial cancer, was approved in December 2019; sales of its first ADC product, lymphoma treatment Adcetris (brentuximab vedotin; an ADC comprising a chimeric anti-CD30 IgG1 mAb conjugated to four molecules of MMAE via a protease-cleavable maleimidocaproyl valine-citrulline linker), which is sold outside of the United States by Takeda, reached $\$ 1$ billion in 2019, even though US sales have slightly disappointed. This, along with pipeline progress and
$\$ 575$ million of follow-on financing in July, helped the company more than double its value (to $\$ 19$ billion) in 2019 , entering the top 10 biotechs by value. That meant massive returns for the company's largest shareholder, Baker Bros. Advisors, a secretive hedge fund run by billionaires Julian and Felix Baker, which first invested over 15 years ago.

Seattle Genetics' progress continued in 2020. The FDA and the Swiss authorities approved small-molecule kinase inhibitor Tukysa (tucatinib) for use in combination with capecitabine and Herceptin (trastuzumab) for patients with HER2-positive metastatic breast cancer. 
Table 5 | Top ten mergers and acquisitions of 2019

\begin{tabular}{llll} 
Target & Acquirer & Value (\$ millions) & Closing date \\
\hline Celgene & Bristol-Myers Squibb & 74,000 & 3 January \\
Array BioPharma & Pfizer & 11,400 & 17 June \\
\hline The Medicines Company & Novartis & 9,700 & 24 November \\
Loxo Oncology & Eli Lilly & 7,234 & 7 January \\
Spark Therapeutics & Roche & 4,300 & 25 February \\
Audentes Therapeutics & Astellas & 3,000 & 2 December \\
Genomic Health & Exact Sciences & 2,800 & 29 July \\
ArQule & Merck & 2,700 & 9 December \\
Synthorx & Sanofi & 2,500 & 9 December \\
Ra Pharma & UCB & 2,300 & 10 October \\
\hline
\end{tabular}

Source: $\mathrm{BCIQ}$ BioCentury Online Intelligence

nods and growing confidence of their utility among prescribers and the physician community. Last year, the FDA approved 48 new medicines, more than in any year in the decade other than 2018, which saw a bumper 59 approvals. Nearly half of the new drugs were for rare diseases, including rare cancers. They included BeiGene's Brukinsa (zanubrutinib) for mantle cell lymphoma, a rare form of non-Hodgkin's lymphoma; Alnylam's Givlaari (givosiran), an RNAi-based medicine for adults with acute hepatic porphyria; and two gene therapies: the ex vivo Zolgensma (onasemnogene abeparvovec; an adeno-associated viral vector serotype 9 (AAV-9)-based gene therapy encoding the human survival motor neuron $(\mathrm{SMN})$ protein under the control of a cytomegalovirus enhancer/ chicken- $\beta$-actin hybrid promoter) was approved for spinal muscular atrophy by the FDA's Center for Biologics Evaluation $\&$ Research division (Novartis acquired developer AveXis for $\$ 8.7$ billion in 2018); and Sarepta's Vyondys 53 (golodirsen; an antisense phosphorodiamidate morpholino oligonucleotide) got the nod, after an earlier rejection, for Duchenne muscular dystrophy (DMD) in patients with a confirmed mutation amenable to exon 53 skipping.

The high number of drug approvals in 2019 allowed several large-cap (valued at over $\$ 5$ billion) yet loss-making biotechs to graduate from single- to multiple-product companies, moving them a step closer to self-sustainability. Cancer company Seattle Genetics, RNAi-focused Alnylam and antisense oligonucleotide developer Sarepta were among them. Biotech companies' increasing contributions to overall medicines approvals means more companies with steady revenue streams (whether

\section{Box 6 | Cancer and gene therapy dominates M\&A ranks}

Eli Lilly's \$7.2-billion purchase of targeted-cancer drug pioneer Loxo Oncology strengthens Lilly's oncology portfolio and helps fill the \$1.4-billion gap left by erectile dysfunction drug Cialis, hit with generic competition in 2018. Loxo's Vitrakvi (larotrectinib) was the first drug to receive FDA approval (in late 2018) for use on the basis of genetic mutation, rather than tumor location. Pfizer's \$11.4-billion purchase of Array BioPharma in June was driven by a similar urge to build out oncology and catch up with domain leaders Merck, Roche and the newly enlarged Bristol-Myers Squibb. The draw: approved BRAF/MEK small-molecule inhibitor combo encorafenib (Braftovi) and binimetinib (Mektovi) for BRAF-mutant unresectable or metastatic melanoma, also in tens of further clinical trials, for indications including BRAF-mutant metastatic colorectal cancer.

Merck was not standing still in the race to dominate the multiplying categories of genetically targeted cancers. In December 2019 , it announced a \$2.7-billion deal to buy ArQule with its phase 2 oral Bruton's tyrosine kinase (BTK) inhibitor for B-cell malignancies.

Evidence of the accelerated

value-creation possible for cancer-focused biotechs came from Sanofi's \$2.5-billion cash deal in December 2019 for La Jolla, California-based immuno-oncology firm Synthorx - founded just five years earlier from Floyd Romesberg's lab at the Scripps Research Institute, with a \$6.25-million series A. The company's platform for introducing unnatural amino acids allows new pharmacological properties to be encoded into lymphokines and other proteins. Synthorx raised about $\$ 230$ million in total, including $\$ 150$ million in its 2018 IPO.

Not all of 2019's multi-billion-dollar deals were around cancer. Novartis's \$9.7-billion Medicines Company purchase, announced in November, bet on inclisiran, an RNAi-based treatment licensed from Alnylam for treating high cholesterol. The Medicines Company filed for approval in the United States and Europe. Novartis is hoping the drug, whose phase 3 trials were in atherosclerotic cardiovascular disease and familial hypercholesterolemia, will trump Amgen's Repatha (evolocumab; a human IgG2 mAb targeting human proprotein convertase subtilisin kexin 9 (PSCK9)) and Regeneron's Praluent (alirocumab) on the basis of convenience. Those drugs (which target the PSCK9 protein itself) require injection once or twice a month; their sales have disappointed. Inclisiran's mechanism enables a more convenient twice-yearly subcutaneous dosing regimen - an advantage that the COVID-19 experience may amplify further still.

Roche's \$4.3-billion Spark Therapeutics purchase and Astellas' \$3-billion deal to buy Audentes underscored gene therapy's successful ongoing journey from experimental to established modality. Spark's Luxturna (voratigene neoparvovec) in 2017 became the first AAV-based gene therapy to be approved in the United States, for retinal dystrophy caused by biallelic RPE65 gene mutation. The company's pipeline spans blindness, hemophilia and lysosomal storage disorders. Audentes brings to Astellas a fifth growth pillar around genetic medicine, driven by lead clinical candidate AT132, which uses an AAV-8 vector to deliver a functional copy of the myotubularin 1 (MTM1) gene, whose absence causes the rare neuromuscular disorder X-linked myotubular myopathy.

Both Spark and Audentes will continue to operate as quasi-independent units within their respective parent companies a partial nod to Roche's pioneering Genentech partnership more than two decades ago. 
Table 6 | Top ten licensing deals of 2019

\begin{tabular}{|c|c|c|c|}
\hline Companies involved (role) & Description & $\begin{array}{l}\text { Date } \\
\text { announced }\end{array}$ & $\begin{array}{l}\text { Up-front cash } \\
\text { (\$ millions) }\end{array}$ \\
\hline $\begin{array}{l}\text { Galapagos (licensor), Gilead Sciences } \\
\text { (licensee) }\end{array}$ & $\begin{array}{l}\text { Galapagos grants Gilead exclusive, ex-European product license and option } \\
\text { rights to develop and commercialize current and future programs }\end{array}$ & 07/14/2019 & 3,950 \\
\hline Amgen (licensor), BeiGene (licensee) & Amgen partners with BeiGene to expand oncology presence in China & $10 / 31 / 2019$ & 2,700 \\
\hline $\begin{array}{l}\text { Roche (licensee), Sarepta Therapeutics } \\
\text { (licensor) }\end{array}$ & $\begin{array}{l}\text { Sarepta grants Roche exclusive, ex-US rights to develop and commercialize } \\
\text { SRP-9001 to treat DMD }\end{array}$ & $12 / 23 / 2019$ & 750 \\
\hline $\begin{array}{l}\text { Alnylam Pharmaceuticals (licensor), } \\
\text { Regeneron Pharmaceuticals (licensee) }\end{array}$ & $\begin{array}{l}\text { Alnylam and Regeneron partner in a five-year deal to discover, develop and } \\
\text { commercialize RNAi therapeutics }\end{array}$ & 04/08/2019 & 400 \\
\hline $\begin{array}{l}\text { Adaptive Biotechnologies (licensor), } \\
\text { Genentech (licensee), Roche (other) }\end{array}$ & $\begin{array}{l}\text { Adaptive Biotechnologies partners with Roche's Genentech unit to develop } \\
\text { personalized and off-the-shelf T cell therapies to treat cancer }\end{array}$ & $01 / 04 / 2019$ & 300 \\
\hline $\begin{array}{l}\text { Akcea Therapeutics (licensor), lonis } \\
\text { Pharmaceuticals (other), Pfizer (licensee) }\end{array}$ & $\begin{array}{l}\text { Akcea grants Pfizer exclusive, worldwide rights to develop and commercialize } \\
\text { AKCEA-ANGPTL3-LRx to treat cardiovascular and metabolic diseases }\end{array}$ & 10/07/2019 & 250 \\
\hline $\begin{array}{l}\text { Jazz Pharmaceuticals (licensee), } \\
\text { PharmaMar (licensor) }\end{array}$ & $\begin{array}{l}\text { PharmaMar grants Jazz Pharmaceuticals exclusive US rights to develop and } \\
\text { commercialize lurbinectedin }\end{array}$ & $12 / 19 / 2019$ & 200 \\
\hline $\begin{array}{l}\text { Dicerna Pharmaceuticals (licensor), } \\
\text { Roche (licensee) }\end{array}$ & $\begin{array}{l}\text { Dicerna grants Roche worldwide rights to develop and commercialize } \\
\text { DCR-HBVS and additional therapies to treat hepatitis B virus infection }\end{array}$ & $10 / 31 / 2019$ & 200 \\
\hline $\begin{array}{l}\text { Dicerna Pharmaceuticals (licensor), } \\
\text { Novo Nordisk (licensee) }\end{array}$ & $\begin{array}{l}\text { Dicerna partners with Novo Nordisk to discover and develop therapies for } \\
\text { the treatment of liver-related cardiometabolic diseases using Dicerna's GalXC } \\
\text { RNAi platform technology }\end{array}$ & $11 / 18 / 2019$ & 175 \\
\hline $\begin{array}{l}\text { CRISPR Therapeutics (licensor), } \\
\text { Vertex Pharmaceuticals (licensee) }\end{array}$ & $\begin{array}{l}\text { CRISPR grants Vertex exclusive, worldwide rights to its current and future } \\
\text { intellectual property covering CRISPR-Cas9 technology, endonucleases, } \\
\text { single- and double-cut guide RNAs and adeno-associated viral vectors to } \\
\text { develop DMD and DM1 gene-editing therapies }\end{array}$ & 06/06/2019 & 175 \\
\hline
\end{tabular}

Source: BCIQ BioCentury Online Intelligence

from product sales or royalties) that lenders feel confident lending to. In early 2020, private equity group Blackstone Life Sciences lent Alnylam $\$ 750$ million as part of a larger, $\$ 2$ billion deal designed to bridge the biotech across to financial self-sustainability (Box 5).

\section{Billion-dollar babies}

Acquisitions and partnerships, as usual, accounted for the lion's share of public biopharma financing in 2019. Merger and acquisition (M\&A) totals were dominated by the completion in January of Bristol-Myers Squibb's previously announced acquisition of Celgene. The year's M\&A cash haul of $\$ 90.5$ billion was below 2018's $\$ 103$ billion, but there were $25 \%$ more deals worth over $\$ 1$ billion upfront (Table 5 and Box 6). Many of them underscored the continued popularity of targeted oncology, immunology and rare-disease assets, as well as an increasing confidence in experimental therapy platform technologies using oligonucleotide, gene- or cell-therapy modalities.

The ghost of Roche's now decades-old yet pioneering partnership with Genentech featured in 2019's biggest partnership deal. Gilead's ten-year tie-up with Galapagos, announced in July, included a \$3.95-billion up-front payment and $\$ 1.1$ billion in equity investment. It gave Gilead first dibs on all of the group's pipeline of small molecules, spanning inflammatory diseases, fibrosis and osteoarthritis (Table 6). Notably, the deal fell short of an outright acquisition: Galapagos maintains R\&D independence, but can't sell out to anyone else (or indeed to Gilead). The tie-up drove a $170 \%$ increase in Galapagos's share price over the year, valuing the 20-year old company, which has yet to produce a marketed drug, at $\$ 13$ billion by 31 December.

The rest of 2019's top-ten licensing deals featured the same heady mix of oncology and rare-disease assets, underpinned by oligonucleotide, geneor cell-therapy technologies. Roche in December paid $\$ 750$ million for ex-US development and commercialization rights to Sarepta's clinical-stage gene therapy SRP-9001 (an AAVrh74 vector containing a codon-optimized human microdystrophin transgene driven by MHCK7, a cardiac-muscle-specific hybrid promoter comprising enhancer and promoter regions of the murine muscle creatine kinase and $\alpha$-myosin heavy-chain genes) for DMD. Sarepta's valuation had already doubled during 2018 as revenues rolled in from its first DMD drug, Exondys (eterplirsen); the company finished 2019 another 25\% higher, worth $\$ 9.6$ billion - a whisker outside the top 20 biotechs by market capitalization.
Alnylam and Regeneron joined forces in April to discover, develop and sell RNAi therapeutics, primarily for eye and central nervous disorders. Elsewhere, Lexington, Massachusetts-based Dicerna Pharmaceuticals - which, rather than 21-mer double-stranded RNAs, uses Dicer-substrate 25/27-mer asymmetric double-stranded RNAs containing stabilizing RNA tetra-loops (DsiRNAs) - signed up Roche and Novo Nordisk in the final quarter of 2019.

Most biotech companies aren't in the multi-billion-dollar league. Many will have started 2020 with much less generous cash cushions; more than a few of those will have seen their clinical trial progress slowed or stopped by the pandemic, making lucrative deals or refinancing even less likely. The sector as a whole may be weathering the COVID-19 storm very well indeed, but at company level, there will be plenty of losers, too.

MelanieSenior

London, UK.

Published online: 30 June 2020

https://doi.org/10.1038/s41587-020-0593-1

Additional information

Supplementary information is available for this paper at https://doi.org/10.1038/s41587-020-0593-1. 